\title{
ANALYSIS OF NO2 TROPOSPHERIC COLUMN AMOUNT AT AIRPORTS IN MALAYSIA BEFORE AND DURING COVID-19 PANDEMIC USING SENTINEL-5P TROPOMI DATA
}

\author{
Kasturi Devi Kanniah ${ }^{1,2 *}$, Nurul Amalin Fatihah Kamarul Zaman ${ }^{1}$ and Kannan Perumal ${ }^{3}$ \\ ${ }^{1}$ Tropical Map Research Group, Faculty of Built Environment \& Surveying, Universiti Teknologi Malaysia, 81310 Skudai, Johor, \\ Malaysia - kasturi@utm.my, nafatihah4@graduate.utm.my \\ ${ }^{2}$ Centre for Environmental Sustainability and Water Security (IPASA), Research Institute for Sustainable Environment, Universiti \\ Teknologi Malaysia, 81310 UTM, Skudai, Johor, Malaysia \\ ${ }^{3}$ Azman Hashim International Business School, Universiti Teknologi Malaysia, 81310 UTM, Skudai, Johor, Malaysia - \\ pkannan@ibs.utm.my
}

KEY WORDS: $\mathrm{NO}_{2}$, aviation emission, Sentinel-5p, Remote Sensing, Malaysia, COVID-19

\begin{abstract}
:
Air pollution is a serious environmental and health issue in Malaysia due to the recent urbanization processes. The main sources of air pollutants are motorized vehicles in urban areas and airports and industrial activities. At the airports, $\mathrm{NO}_{2}$ is the main pollutant of concern besides aerosols particles, yet gap in data availability prevent studies to describe their patterns and quantify their effects on human health and climate change. In this study $\mathrm{NO}_{2}$ data from TROPOMI sensor on board Sentinel 5-P satellite was used to characterize the spatial and temporal patterns of $\mathrm{NO}_{2}$ tropospheric column amounts at major airports in Malaysia. The results demonstrate that $\mathrm{NO}_{2}$ amounts from aircrafts and ground traffic activities are generally higher and/or similar to the amounts found in urban areas. Total tropospheric column amounts of $\mathrm{NO}_{2}$ during the movement restriction imposed due to Covid-19 pandemic between March and April 2020 was approximately 50\% lower the total emission during the same period in 2019 (representing a business as usual period). Assessing the spatial pattern and temporal variations in $\mathrm{NO}_{2}$ (both surface and total vertical profile) is important for monitoring the impact of air pollutants on climate change and human health in Malaysia.
\end{abstract}

\section{INTRODUCTION}

Air pollution is a serious environmental issue in Malaysia in recent years as Malaysia is developing into an urbanized and industrialized nation (Latif et al., 2018). Industrialization and fossil fuel combustion are the major sources of air pollutants originating from mobile (motorized vehicles on the road, aeroplanes and trains) and stationary (industries and power plants) sources (Usmani et al., 2020). Aircraft and other surface traffic movements generate large amount of greenhouse gases and other aerosol particles at the airports (Environmental Protection., 2021). The major air pollutants at airports and their vicinities is aerosol particles and nitrogen dioxide $\left(\mathrm{NO}_{2}\right)$ that are formed by nitrogen oxides emitted by aircrafts and other automobiles operating at airports (Fanning et al., 2007; Dumka et al., 2019). Globally aviation industry is responsible for emitting $1.9 \%$ of greenhouse gases and contributes to $3.5 \%$ of global warming (Lee et al., 2021). Aviation industry is expanding over time as it is one of the important economic activities, thus its contribution to air pollution, climate change (Zhang et al., 2020) and human health is significant. At high concentration near the Earth's surface, $\mathrm{NO}_{2}$ can bring lethal impacts to human health by causing respiratory diseases (He et al., 2020).

Previous studies emphasizing on air quality deterioration as a consequence of aviation activities have been conducted near the downwind areas. Hudda et al. (2020) estimated up to 5 times higher $\mathrm{CO}, \mathrm{CO}_{2}, \mathrm{NO}$ and $\mathrm{NO}_{2}$ in a housing area located near the Boston, USA airport. At Heathrow Airport, London Carslaw et al. (2006) reported that aircraft and other ground traffic activities emitted oxides of nitrogen near the runway. Aircrafts were also found to double the concentration of sulfur dioxide near to Hong
Kong International Airport (Yu et al., 2004). Significant increase in air pollutants at or downwind of airports are also reported by Fanning et al. (2007) (PM<10 $\mu \mathrm{m})$, and Dodson et al. (2009) (total black carbon). These studies show the impact of aircrafts on deteriorated air quality in major airports around the world and motivated the authors to conduct the current study. In Malaysia $\mathrm{NO}_{2}$ concentration has been recorded to be highest at urban sites (12-13 ppb- yearly average) and between 23 and $40 \mathrm{ppb}$ at industrial sites (hourly average) mainly due to vehicle and industrial emissions (Mohtar et al., 2018; Kanniah et al., 2020). However, studies analysing the $\mathrm{NO}_{2}$ tropospheric column amounts and their patterns at airports are not available. The air quality monitoring stations operated by the Department of Environment, Malaysia (DOE) do not cover airport locations, thus their contributions to air pollution or climate change is largely unknown.

Remote sensing is an alternative valuable tool (in the absence of ground monitoring stations) for investigating the concentration and variability of air pollution i.e. $\mathrm{NO}_{2}$ within airports in Malaysia. Different satellites with various sensors that measure a variety of gases and particles at different spatial resolutions have been launched. Table 1 summarizes the remote sensing instruments used to derive $\mathrm{NO}_{2}$ data. The recently available (launched in October 2017) TROPOMI (TROPOspheric Monitoring Instrument) sensor on board the European Space Agency's Sentinel $5 \mathrm{P}$ satellite provides $\mathrm{NO}_{2}$ data at high spatial resolution, high temporal revisits and better accuracy (Griffin et al., 2019) compared to earlier satellites (Table 1). This data provides an opportunity to characterize air pollution in a better way at local scales (airports, cities and industrial areas). The objective of this study is to use the Sentinel 5P satellite data to

\footnotetext{
${ }^{*}$ Corresponding author
} 
describe the patterns of $\mathrm{NO}_{2}$ tropospheric column amounts around major airports in Malaysia. The results of the study will be useful for management authorities i.e. Malaysia Airport
Holdings Berhad to assess air quality of airports and quantify their contributions to climate change.

\begin{tabular}{|c|c|c|c|c|}
\hline Satellite/Sensor & $\begin{array}{l}\text { Atmospheric constituents } \\
\text { measured }\end{array}$ & Operational period & Pixel size & Reference \\
\hline $\begin{array}{l}\text { Global Ozone Monitoring } \\
\text { Experiment (GOME) }\end{array}$ & $\begin{array}{l}\mathrm{O}_{3}, \mathrm{NO}_{2}, \mathrm{BrO}, \mathrm{H}_{2} \mathrm{O}, \mathrm{O}_{4} \\
\mathrm{SO}_{2}, \mathrm{NO}_{3}, \mathrm{H}_{2} \mathrm{CO}\end{array}$ & $1995-2011$ & $\begin{array}{l}40 \times 320 \\
\mathrm{~km}^{2}\end{array}$ & Burrows et al. (1999) \\
\hline $\begin{array}{l}\text { SCanning Imaging Absorption } \\
\text { SpectroMeter for Atmospheric } \\
\text { Cartography (SCIAMACHY) }\end{array}$ & $\begin{array}{l}\mathrm{O}_{3}, \mathrm{NO}_{2}, \text { hypobromite } \\
(\mathrm{BrO}), \mathrm{CO}, \mathrm{CH}_{4}, \mathrm{H}_{2} \mathrm{O}, \\
\mathrm{N}_{2} \mathrm{O}, \mathrm{SO}_{2}\end{array}$ & 2002-2012; & $\begin{array}{l}30 \times 60 \\
\mathrm{~km}^{2}\end{array}$ & $\begin{array}{l}\text { Bovensmann et al. } \\
\text { (1999) }\end{array}$ \\
\hline GOME-2 instruments & $\begin{array}{l}\mathrm{O}_{3}, \mathrm{O}_{2}, \mathrm{NO}_{2}, \mathrm{BrO}, \mathrm{H}_{2} \mathrm{O} \\
\mathrm{O}_{4}, \mathrm{SO}_{2}, \mathrm{HCHO}, \mathrm{OCIO}\end{array}$ & 2012-present & $\begin{array}{l}40 \times 4080 \\
\mathrm{~km}^{2}\end{array}$ & Callies et al. (2000) \\
\hline $\begin{array}{l}\text { Ozone Monitoring Instrument } \\
\text { (OMI) }\end{array}$ & $\mathrm{O} 3, \mathrm{NO}_{2}, \mathrm{SO}_{2}$ and aerosol & 2004-present & $\begin{array}{l}13 \times 24 \\
\mathrm{~km}^{2}\end{array}$ & Krotkov et al. (2016) \\
\hline $\begin{array}{l}\text { Sentinel-5 Precurser (S5P), } \\
\text { TROPOMI sensor }\end{array}$ & $\begin{array}{l}\mathrm{CO}, \text { formaldehyde } \\
(\mathrm{HCHO}), \mathrm{NO}_{2}, \mathrm{O}_{3}, \mathrm{SO}_{2}, \\
\text { methane }\left(\mathrm{CH}_{4}\right)\end{array}$ & Since Oct 2017 & $\begin{array}{l}3.5 \times 7.0 \\
\mathrm{~km}\end{array}$ & Ialongo et al. (2020) \\
\hline
\end{tabular}

Table 1. Satellites/sensors providing atmospheric gases data

\section{DATA AND METHODOLOGY}

\subsection{Study Area}

In this study, we focussed on the $\mathrm{NO}_{2}$ tropospheric column amounts at 67 locations namely airports ( 2 locations), industrial (7 locations), urban (10 locations), suburban (36 locations) and rural (12 locations). At all the locations except for the airports, the Department of Environment, Malaysia operates air quality monitoring stations. Although our focus is on airports (under studied land use for their contribution in air pollution) we extracted $\mathrm{NO}_{2}$ values for other locations for a comparative analysis (Figure 1).

Kuala Lumpur International Airport (KLIA) is located approximately $45 \mathrm{~km}$ to the south of Kuala Lumpur, the capital city of Malaysia (latitude $2.7547968^{\circ}$, and longitude $101.7040779^{\circ}$ ). KLIA and KLIA 2 (located at latitude 2.7441624 ${ }^{\circ}$ and longitude $101.6853691^{\circ}$ ) are two terminals in the same area separated by $2 \mathrm{~km}$. In 2018, the airport managed almost 60 million passengers, 714,000 tonnes of cargo and 400,000 aircraft movements making it one of the world's busiest airport (https://www.klia2.info/klia/). The KLIA airport is operated by Malaysia Airports (MAHB) and it covers a land area of $10 \mathrm{~km} \mathrm{x}$ $10 \mathrm{~km}$. Besides aircrafts, the movement of other ground transportation (trains, buses and cars) also potentially contribute to the tropospheric column amounts of $\mathrm{NO}_{2}$.

\subsection{Data Processing}

$\mathrm{NO}_{2}$ Data from the TROPOMI sensor on board the Sentinel-5P satellite was downloaded from https://s5phub.copernicus.eu/dhus/\#/home website. Sentinel- 5P operates at a Sun-synchronous orbit and overpasses Malaysia two times daily between $11 \mathrm{am}$ and $2.40 \mathrm{pm}$ (Hu et al., 2018). TROPOMI sensor operates using ultraviolet, near infrared and shortwave infrared wavelengths and the ultraviolet-near infrared spectrometer $(405-465 \mathrm{~nm})$ was used to estimate the vertical column density of $\mathrm{NO}_{2}$ in units of $\mathrm{mol} \mathrm{m}^{-2}$ (Boersma et al., 2011). The accuracy of the product is approximately $30-40 \%$ for snowfree areas (Boersma et al., 2011). In this study we used the L2_NO2 (nitrogendioxide tropospheric_column_PRODUCT). The $\mathrm{NO}_{2}$ L2 retrieval associated with quality assurance value $>0.75$ are used to remove cloud and snow cover, errors and problematic retrievals (Eskes and Eichmann, 2018). The product was reprojected into WGS84 Datum using the SNAP software. We then extracted $\mathrm{NO}_{2}$ values for a single pixel (coinciding with the coordinates covering the airport and also other 65 locations that represent the industry, urban, sub-urban and rural areas in Malaysia (Kanniah et al., 2020). $\mathrm{NO}_{2}$ tropospheric column amounts from the airport was compared with the tropospheric column amounts from other locations to infer the contribution of airports in $\mathrm{NO}_{2}$ amounts. The spatial resolution of the $\mathrm{NO}_{2}$ data used in this study varies from $3.5 \times 7.0 \mathrm{~km}$ (across $\mathrm{x}$ along track), at beginning of mission and $3.5 \times 5.5 \mathrm{Km}$ (across $\mathrm{x}$ along track) since 6 August 2019. We downloaded daily data from 18 March to $30^{\text {th }}$ April 2019 and 18 March to 30th April 2020, a total of 85 images for each year respectively.

\section{RESULT AND DISCUSSION}

The vertical column density values of $\mathrm{NO}_{2}$ from the Kuala Lumpur International Airport (KLIA) and other locations covering urban, industry, sub-urban and rural areas is shown in Figure 1. The values are shown for two periods; Mar-Apr 2019 (pre Covid-19 pandemic period) and Mar-Apr 2020 (during the pandemic lock down period). The total $\mathrm{NO}_{2}$ amounts in 2020 was $0.00004 \mathrm{~mol} \mathrm{~m}^{-2}$, a reduction of $50 \%$ compared to the amount in 2019. The highest $\mathrm{NO}_{2}$ values were found in urban areas and at the airports ( 800 and $750 \mu \mathrm{mol} / \mathrm{m}^{2}$ respectively). Similar to the airports, the urban areas also recorded a reduction of more than $50 \%$ in 2020 compared to 2019 . Other locations such as suburban recorded a reduction of $\sim 40 \%$ between the two periods, meanwhile only a small percentage decrease was found in rural and industrial areas. The spatial distribution of $\mathrm{NO}_{2}$ column density is shown in Figure 2. Figure 2 also shows the locations of urban, industry, sub-urban and rural areas considered in this study. High $\mathrm{NO}_{2}$ values (maximum of $1700 \mu \mathrm{mol} / \mathrm{m}^{2}$ ) were found in the west coast of Peninsular Malaysia that is the hub for industrial activities and urban centres.

The lockdown due to Covid-19 pandemic disrupted human activities around the world between March and April 2020. Consequently, remarkable decrease in major air pollutants 
particularly $\mathrm{NO}_{2}$ and particulate matters was recorded in many countries. In SEA, large reductions in $\mathrm{PM}_{2.5}$ was recorded in several urban areas in Malaysia (Kanniah et al., 2020), Thailand and the Philippines (Arkin, 2020).

We further analysed the variation in $\mathrm{NO}_{2}$ values at the airport (10 $\mathrm{km}$ radius) and nearby locations surrounded by sub-urban areas (Figure 3). The $\mathrm{NO}_{2}$ tropospheric column amounts from the airport is higher to the north direction of the airport in 2019. This may be due to the wind direction where more concentration of $\mathrm{NO}_{2}$ is found at the downwind especially aircrafts landing from the north. There are many industrial areas located in the north direction of the airport (Puchong, Kota Kemuning, Petaling Jaya and Dengkil) that may have also contributed to the concentration of $\mathrm{NO}_{2}$ especially at the lower part of the troposphere. In 2020 however, the values were much lower and no noticeable pattern in the values are found in the surrounding areas. This result shows that pollutants originated from the airport during the "business as usual" time (2019) influenced higher pollution level in the surrounding areas as well.

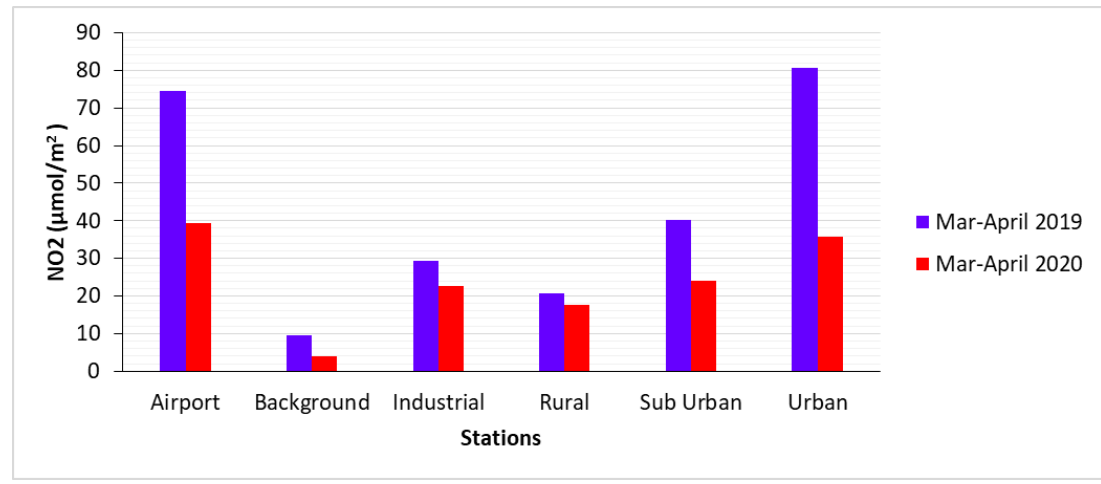

Figure 1. The vertical column density values of $\mathrm{NO}_{2}\left(\mu \mathrm{mol} / \mathrm{m}^{2}\right)$ from the Kuala Lumpur International Airport (KLIA) and other locations covering urban, industry, sub-urban and rural areas for March-April 2019 and 2020.

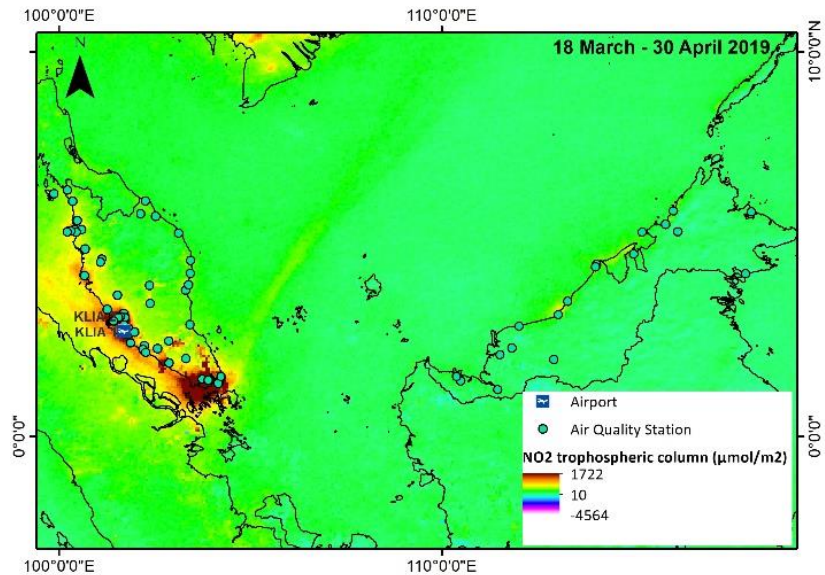

(a)

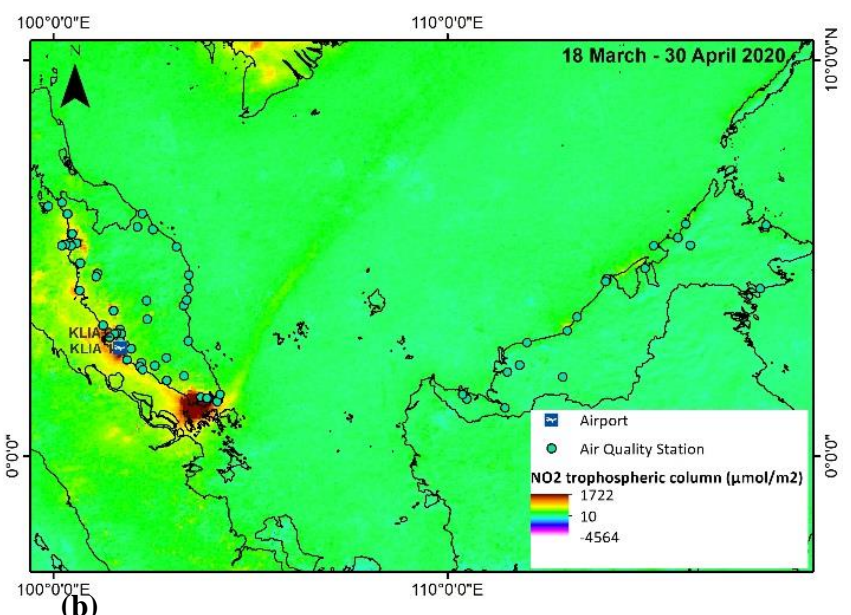

(b)

Figure 2. Spatial distribution of $\mathrm{NO}_{2}$ tropospheric column amounts in Malaysia for March-April 2019(a) and 2020 (b) 

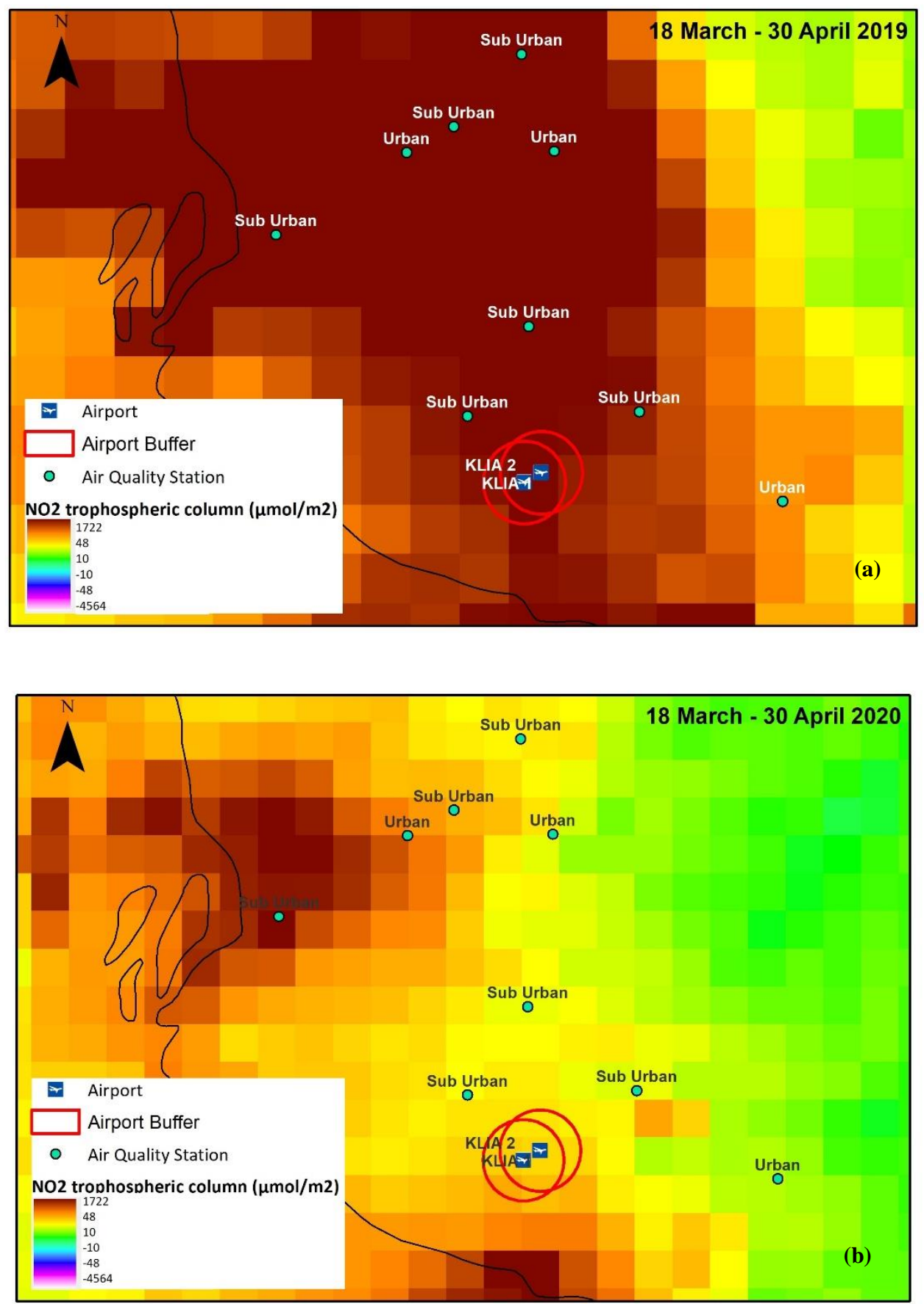

Figure 3. $\mathrm{NO}_{2}$ variations at the airport and nearby locations in 2019 (a) and 2020 (b). Values of the pixels are $\mathrm{NO}_{2}$ in $\mu \mathrm{mol} / \mathrm{m}^{2}$

\section{SUMMARY}

The preliminary results obtained in this study show that $\mathrm{NO}_{2}$ tropospheric column amounts originating from aircrafts and other vehicular activities at airports in Malaysia are generally higher and/or similar to the amounts found from urban areas. This study also found that the total tropospheric column amounts during the movement restrictions due to the Covid-19 pandemic was at least $50 \%$ less than the values recorded in 2019 (representing a business as usual period). It should be noted that in the SEA region, biomass burning is also responsible for the release and concentration of ttropospheric $\mathrm{NO}_{2}$ in the atmosphere (Itahashi et al., 2018). Other meteorological factors such as solar radiation, rainfall and advection can also influence the amount of $\mathrm{NO}_{2}$ in the troposphere and these factors must be analysed in the future. Although TROPOMI sensor provides columnar $\mathrm{NO}_{2}$ quantity, the data may be useful to monitor changes occurring in $\mathrm{NO}_{2}$ concentrations near the Earth's surface. Assessing the temporal and geographical variations in $\mathrm{NO}_{2}$ (both surface and total vertical profile) is important for investigating the impact of this gas on human health and climate change in Malaysia. 


\section{ACKNOWLEDGEMENTS}

The authors acknowledge the Ministry of Education, Malaysia via the Fundamental Research Grant (FRGS/1/2019/WAB05/UTM/02/3)

\section{REFERENCES}

Arkin, F. (2020). Asian COVID-19 lockdowns clear the air of pollutants. . Retrieved 5 August 2020, from https://www.scidev.net/asiapacific/environment/news/asian-covid-19lockdownsclear-the-air-of-pollutants.html

Boersma, K., Eskes, H., Dirksen, R., Van Der A, R., Veefkind, J., Stammes, P., et al. (2011). An improved tropospheric NO 2 column retrieval algorithm for the Ozone Monitoring Instrument. Atmospheric Measurement Techniques, 4(9), 1905-1928.

Bovensmann, H., Burrows, J., Buchwitz, M., Frerick, J., Noël, S., Rozanov, V., et al. (1999). SCIAMACHY: Mission objectives and measurement modes. Journal of the atmospheric sciences, 56(2), 127-150.

Burrows, J. P., Weber, M., Buchwitz, M., Rozanov, V., Ladstätter-Weißenmayer, A., Richter, A., et al. (1999). The global ozone monitoring experiment (GOME): Mission concept and first scientific results. Journal of the Atmospheric Sciences, 56(2), 151-175.

Callies, J., Corpaccioli, E., Eisinger, M., Hahne, A., and Lefebvre, A. (2000). GOME-2-Metop's secondgeneration sensor for operational ozone monitoring. ESA bulletin, 102, 28-36.

Carslaw, D. C., Beevers, S. D., Ropkins, K., and Bell, M. C. (2006). Detecting and quantifying aircraft and other on-airport contributions to ambient nitrogen oxides in the vicinity of a large international airport. Atmospheric Environment, 40(28), 5424-5434.

Dodson, R. E., Houseman, E. A., Morin, B., and Levy, J. I. (2009). An analysis of continuous black carbon concentrations in proximity to an airport and major roadways. Atmospheric Environment, 43(24), 37643773.

Dumka, U. C., Tiwari, S., Kaskaoutis, D. G., Soni, V. K., Safai, P. D., and Attri, S. D. (2019). Aerosol and pollutant characteristics in Delhi during a winter research campaign. Environmental Science and Pollution Research, 26(4), 3771-3794.

Environmental Protection., U. (2021). Retrieved 4 Feb 2021, from https://www.environmentalprotection.org.uk/policy-areas/air-quality/airpollution-and-transport/aviation-pollution/

Eskes, H., and Eichmann, K. (2018). S5P Mission Performance Centre Nitrogen Dioxide [L2 _ NO2__ ] Readme document: S5P-MPC-KNMI-PRF-NO2, KNMI, available at: https://sentinel. esa. int ...o. Document Number)

Fanning, E., Yu, R. C., Lu, R., and Froines, J. (2007). Monitoring and Modeling of Ultrafine Particles and Black Carbon at the Los Angeles International Airport. California Air Resources Board.

Griffin, D., Zhao, X., McLinden, C. A., Boersma, F., Bourassa, A., Dammers, E., et al. (2019). High-resolution mapping of nitrogen dioxide with TROPOMI: First results and validation over the Canadian oil sands. Geophysical Research Letters, 46(2), 1049-1060.

He, M. Z., Kinney, P. L., Li, T., Chen, C., Sun, Q., Ban, J., et al. (2020). Short-and intermediate-term exposure to NO2 and mortality: a multi-county analysis in China. Environmental Pollution, 261, 114165.

Hu, H., Landgraf, J., Detmers, R., Borsdorff, T., Aan de Brugh, J., Aben, I., et al. (2018). Toward global mapping of methane with TROPOMI: First results and intersatellite comparison to GOSAT. Geophysical Research Letters, 45(8), 3682-3689.

Hudda, N., Durant, L. W., Fruin, S. A., and Durant, J. L. (2020). Impacts of aviation emissions on near-airport residential air quality. Environmental Science \& Technology, 54(14), 8580-8588.

Ialongo, I., Virta, H., Eskes, H., Hovila, J., and Douros, J. (2020). Comparison of TROPOMI/Sentinel-5 Precursor NO 2 observations with ground-based measurements in Helsinki. Atmospheric Measurement Techniques, 13(1), 205-218.

Itahashi, S., Uno, I., Irie, H., Kurokawa, J.-I., and Ohara, T. (2018). Impacts of biomass burning emissions on tropospheric NO 2 vertical column density over continental Southeast Asia. In Land-Atmospheric Research Applications in South and Southeast Asia (pp. 67-81): Springer.

Kanniah, K. D., Zaman, N. A. F. K., Kaskaoutis, D. G., and Latif, M. T. (2020). COVID-19's impact on the atmospheric environment in the Southeast Asia region. Science of The Total Environment, 139658.

Krotkov, N. A., McLinden, C. A., Li, C., Lamsal, L. N., Celarier, E. A., Marchenko, S. V., et al. (2016). Aura OMI observations of regional SO 2 and NO 2 pollution changes from 2005 to 2015. Atmospheric Chemistry and Physics, 16(7), 4605-4629.

Latif, M. T., Othman, M., Idris, N., Juneng, L., Abdullah, A. M., Hamzah, W. P., et al. (2018). Impact of regional haze towards air quality in Malaysia: A review. Atmospheric Environment, 177, 28-44.

Lee, D., Fahey, D., Skowron, A., Allen, M., Burkhardt, U., Chen, Q., et al. (2021). The contribution of global aviation to anthropogenic climate forcing for 2000 to 2018. Atmospheric Environment, 244, 117834.

Mohtar, A. A. A., Latif, M. T., Baharudin, N. H., Ahamad, F., Chung, J. X., Othman, M., et al. (2018). Variation of major air pollutants in different seasonal conditions in an urban environment in Malaysia. Geoscience Letters, 5(1), 21.

Usmani, R. S. A., Saeed, A., Abdullahi, A. M., Pillai, T. R., Jhanjhi, N. Z., and Hashem, I. A. T. (2020). Air pollution and its health impacts in Malaysia: a review. Air Quality, Atmosphere \& Health, 13(9), 1093-1118.

Yu, K., Cheung, Y., Cheung, T., and Henry, R. C. (2004). Identifying the impact of large urban airports on local air quality by nonparametric regression. Atmospheric Environment, 38(27), 4501-4507. 